\author{
A. ASLAN ${ }^{1}$, M. GULLUCE ${ }^{2}$, G. AGAR ${ }^{2}$, \\ M. KARADAYI ${ }^{2}$, S. BOZARI ${ }^{3}$, F. ORHAN ${ }^{4}$ \\ ${ }^{1}$ Department of Biology, Kazim Karabekir Education Faculty, \\ Atatürk University, Erzurum, 25240, Turkey \\ ${ }^{2}$ Department of Biology, Science Faculty, Atatürk University, \\ Erzurum, 25240, Turkey \\ ${ }^{3}$ Department of Biology, Sciences and Arts Faculty, \\ Mus Alparslan University, Mus, 49100, Turkey \\ ${ }^{4}$ Institute of Natural and Applied Sciences, Atatürk University, \\ Erzurum, 25240, Turkey \\ E-mail: mkaradayi@atauni.edu.tr
}

\section{MUTAGENIC AND ANTIMUTAGENIC PROPERTIES OF SOME LICHEN SPECIES GROWN IN THE EASTERN ANATOLIA REGION OF TURKEY}

All the methanol extracts did not show mutagenic activity in Ames/Salmonella and Z. mays MI test systems. Furthermore, some extracts showed significant antimutagenic activity against 9-AA in Ames test system. Inhibition rates for 9-AA mutagenicity ranged from $25.51 \%$ (P. furfuracea $-0.05 \mu \mathrm{g} /$ plate) to $66.14 \%$ (C. islandica $0.05 \mu \mathrm{g} / \mathrm{plate})$. In addition, all of the extracts showed significant antimutagenic activity against sodium azide $\left(\mathrm{NaN}_{3}\right)$ mutagenicity on $\mathrm{MI}$ values of $Z$. mays.

(C) A. ASLAN, M. GULlUCE, G. AGAR, M. KARADAYI, S. BOZARI, F. ORHAN, 2012
Introduction. Cancer is one of the most serious diseases in the World initiated by DNA damage, which caused by natural or synthetic chemicals in the environment $[1,2]$. Many natural or synthetic mutagenic molecules are capable of inducing cancer and many other genetic disorders in living organisms. On the other hand, a number of previous studies have shown that medicinal plants or lichens may have phytochemicals (antimutagens, anticarcinogens etc.) which can strongly inhibit mutations caused by various agents called as mutagens [3-5]. Therefore, studies are currently in progress to identify the mutagens in order to minimize the risk and to evaluate antimutagenic properties of the medicinal plants which can be used to battle against mutations and related diseases including cancer $[5,6]$.

In vivo and in vitro studies showed that some natural compounds which are obtained from the fruits, leaves and roots of plants play regulator roles on xenobiotic effects [7]. The characterization, identification and determination of the antimutagenic and anticarcinogenic effects of these compounds get an important strategy to decrease the development of cancer on human being. Even so some bioactive compounds and their derivatives are observed that inhibiting the carcinogenesis in experimental systems which include beginning, development and spreading phases. Recent research has underlined the chemo-preventive activity of several secondary metabolites [3].

Lichens are symbiotic organisms combining algal and fungal properties. They produce a variety of metabolites. Several lichen extracts and their compounds have been used in traditional medicine in many places around the world [5, 8-11]. Until now chemical composition and some biological (antimicrobial and antioxidant) activities of the extracts of lichens grow in eastern part of Turkey have been reported [12, 13]. However, there have been few attempts to investigate the mutagenic and antimutagenic effects of these lichen extracts, which may have pharmacological importance in mutagenesis prevention. Therefore, the aim of this study was to investigate in vitro mutagenic and antimutagenic properties of the methanol extracts from Cetraria islandica (L.) Ach. (Parmeliaceae), Pseudevernia furfuracea (L.) Zopf (Parmeliaceae) and Xanthoparmelia somloënsis (Gyeln.) Hale (Parmeliaceae) lichens.

Material and methods. Chemicals. Direct acting mutagens sodium azide $\left(\mathrm{NaN}_{3}\right)$ and 9-amino- 
acridine (9-AA) were obtained from Sigma-Aldrich (St. Louis, USA) and Merck (Hohenbrunn, Germany), respectively. Other solvents and pure chemicals including magnesium sulfate $\left(\mathrm{MgSO}_{4}\right)$, sodium ammonium phosphate $\left(\mathrm{Na}_{2} \mathrm{NH}_{2} \mathrm{PO}_{4}\right)$, Dglucose, D-biotin, sodium chloride $(\mathrm{NaCl})$, L-histidine $\mathrm{HCl}$, sodium phosphate-dibasic $\left(\mathrm{Na}_{2} \mathrm{HPO}_{4}\right)$, crystal violet, citric acid monohydrate, potassium phosphate-dibasic $\left(\mathrm{K}_{2} \mathrm{HPO}_{4}\right)$, sodium phosphatemonobasic $\left(\mathrm{NaH}_{2} \mathrm{PO}_{4}\right)$ were also obtained from Difco (New Jersey, USA), Fluka (Steinheim, Germany), Merck (Darmstadt, Germany) and Sigma (St. Louis, USA).

Collection and identification of lichen samples. Lichen specimens were collected from Artvin province in the eastern part of Turkey in 2009 during spring/summer period. Samples were dried at room temperature for $48 \mathrm{~h}$. Identification of samples was made by Dr. Ali Aslan (Kazim Karabekir Education Faculty, Atatürk University, Erzurum - Turkey) by using various flora books [14-16]. The voucher specimens (C. islandica KKEF-705, $P$. furfuracea - KKEF-706 and $X$. somloënsis - KKEF-707) have been deposited at the herbarium of Kazim Karabekir Education Faculty, Atatürk University, Erzurum - Turkey.

Preparation of methanol extracts. Air-dried and powdered lichens $(10 \mathrm{~g})$ were extracted with $250 \mathrm{ml}$ of methanol using the Soxhlet extractor («Isopad», Germany) for $72 \mathrm{~h}$ at a temperature not exceeding the boiling point of the solvent [17]. The extract was filtered using Whatman filter paper (№ 1) and then concentrated in vacuum at $40{ }^{\circ} \mathrm{C}$ using a rotary evaporator (Buchi Labortechnic AG, Flawil, Switzerland) yielding a waxy material. The extract was then lyophilized and kept in the dark at $+4{ }^{\circ} \mathrm{C}$ until tested.

Bacterial Strains. Salmonella typhimurium (Enteriobacteriaceae) TA1535 (ATCC $^{\circledR}$ Num- $^{-}$ ber: 29629) and S. typhimurium TA1537 (ATCC ${ }^{\circledR}$ Number: 29630) strains were provided by The American Type Culture Collection - Bacteria Department of Georgetown University, Washington, USA. These strains were stored at $-80^{\circ} \mathrm{C}$. Working cultures were prepared by inoculating nutrient broth with the frozen cultures, followed by an overnight incubation at $37^{\circ} \mathrm{C}$ with gentle agitation [18].

Viability assays and determination of test concentrations. For bacterial tests, the toxicity of methanol extracts toward $S$. typhimurium TA1535 and 1537 strains was determined as described in detail other manuscripts $[19,20]$. These tests confirmed that there was normal growth of the background lawn, spontaneous colony numbers within the regular range, and no significant reduction in cell survival.

With the aim to determine test concentrations for the mitotic index (MI) values of root tips in Zea mays L. (Poaceae), increasing concentrations of positive control and test materials were prepared. These were exposed to $Z$. mays seeds, and the germination process was evaluated [21, 22].

Thus, for the concentrations and conditions reported here, no toxicity or other adverse effects were observed.

AMES mutagenicity and antimutagenicity test system. Ames test is a biological assay to evaluate the mutagenic and antimutagenic potential of the chemicals. The bacterial mutagenicity and antimutagenicity assays were performed according to described before [23]. The known mutagens $\mathrm{NaN}_{3}$ (in distilled water $-1 \mu \mathrm{g} /$ plate) for $S$. typhimurium TA1535 and 9-AA (in methanol - $10 \mu \mathrm{g}$ / plate) for $S$. typhimurium TA1537 were used as the positive controls and $10 \%$ DMSO was used as the negative control in these studies.

In the mutagenicity test performed with TA1535 and TA1537 strains of S. typhimurium, $100 \mu \mathrm{l}$ of the overnight bacterial culture, $50 \mu \mathrm{l}$ test compounds at different concentrations $(0.05,0.5,5 \mu \mathrm{g} /$ plate in $10 \%$ DMSO), and $500 \mu \mathrm{l}$ phosphate buffer were added to $2 \mathrm{ml}$ of the top agar containing $0.5 \mathrm{mM}$ histidine/biotin. The mixture was poured onto minimal glucose plates. Histidine independent revertant colonies and viable cells were scored on plates after incubation at $37{ }^{\circ} \mathrm{C}$ for $48 \mathrm{~h}$.

In the antimutagenicity test performed with the same strains, $100 \mu \mathrm{l}$ of the overnight bacterial culture, $50 \mu \mathrm{l}$ mutagen, $50 \mu \mathrm{l}$ test compounds at different concentrations $(0.05,0.5,5 \mu \mathrm{g} / \mathrm{plate}$ in $10 \%$ DMSO), and $500 \mu \mathrm{l}$ phosphate buffer were added to $2 \mathrm{ml}$ of the top agar containing $0.5 \mathrm{mM}$ histidine/biotin. The mixture was poured onto minimal glucose plates. Histidine independent revertant colonies and viable cells were scored on plates after incubation at $37{ }^{\circ} \mathrm{C}$ for $48 \mathrm{~h}$.

The plate incorporation method was used to assess the results of mutagenicity and antimutagenicity assays [24]. 
For the mutagenicity assays, the mutagenic index was calculated for each concentration, which is the average number of revertants per plate divided by the average number of revertants per plate with the negative (solvent) control. A sample was considered mutagenic when were observed a dose-response relationship and a two-fold increase in the number of mutants with at least one concentration was observed [25-28].

For the antimutagenicity assays, the inhibition of mutagenicity was calculated by using the following equation (M: number of revertants/plate induced by mutagen alone, $\mathrm{S}_{0}$ : number of spontaneous revertants, $\mathrm{S}_{1}$ : number of revertants/plate induced by the extract plus the mutagen):

$$
\% \text { Inhibition }=1-\left(\frac{M-S_{1}}{M-S_{1}}\right) \times 100
$$

25-40\% Inhibition was defined as moderate antimutagenicity; $40 \%$ or more inhibition as strong antimutagenicity; and $25 \%$ or less inhibition as no antimutagenicity [25, 29, 30].

Mitotic index (MI) values of root tips in Z. mays. Mitotic index reflects cell division frequency and used to determine the mutagenic and antimutagenic properties of various materials as significant parameter [31]. In this study, Zea mays seeds, harvested from an experimental population with ensured uniform genophond, were used to determine mentioned properties of methanol extracts obtained from three lichens ( $C$. islandica, $P$. furfuracea and $X$. somloënsis).

In mutagenicity assays, the Petri dishes containing seeds were exposed to test materials at different concentrations $(5,10,20,40 \mu \mathrm{g} /$ plate $)$. Then, the seeds were let to germinate in controlled environmental conditions into an incubator in dark (Binder, Tuttlingen, Germany). The root tips of germinated seeds were cut and fixed in acetic acid-alcohol (1:3) for $24 \mathrm{~h}$ and were transferred in $70 \%$ alcohol and stored in the fridge. For mitotic preparation, root tips were removed from alcohol and washed with tap water and hydrolised with $1 \mathrm{~N} \mathrm{HCl}$, at $60{ }^{\circ} \mathrm{C}$ for $10 \mathrm{~min}$. Then they were dyed with Feulgen reactive for $3 \mathrm{~h}$ [32]. After that root tips were kept in tap water for $15 \mathrm{~min}$. Finally the last parts of root tips which dyed very densely were cut and their crushing preparations in $45 \%$ acetic acid were made [33, 34].

The procedure of mutagenicity test described above is all applicable to the antimutagenicity as- say. The only procedural difference is the addition of $\mathrm{NaN}_{3}$ as mutagenic agent to Petri dishes.

Mitotic index was calculated by using the following equation and the results are expressed as means \pm standard error

$$
\text { M.I.(\%) }=\frac{\text { TotalCellsInDivision }}{\text { TotalCellsCounted }} \cdot 100 \text {. }
$$

Statistical analysis. The results are presented as the average and standard error of two experiments with duplicate plates/dose experiment. The data were further analyzed for statistical significance using analysis of variance (ANOVA), Student's $t$-test and the difference among means was compared by high-range statistical domain using Tukey's test. A level of probability was taken as $\mathrm{p}<0.05$ indicating statistical significance $[3,21]$.

Results. The results from the Ames test show that the methanol extracts have not any mutagenic activity at tested concentrations (Table 1). Furthermore, these extracts have not any mutagenic effects on $Z$. mays seed germination.

In antimutagenicity assays performed with bacteria, the results show that the methanol extracts have not antimutagenic activity against $\mathrm{NaN}_{3}$ mutagenicity on S. typhimurium TA1535 strain, which detects single nucleotide substations. On the contrary, two of the same extracts including $C$. islandica $(0.05$ and $0.5 \mu \mathrm{g} /$ plate) and $P$. furfuracea $(0.05,0.5$ and $5 \mu \mathrm{g} /$ plate) have antimutagenic activity against 9-AA mutagenicity on S. typhimurium TA1537 strain, which detects frame-shift mutations. The inhibition rates of these extracts were between $25.51 \%$ ( $P$. furfuracea $-0.05 \mu \mathrm{g} /$ plate) and $66.14 \%$ (C. islandica $0.05 \mu \mathrm{g} / \mathrm{plate})$. All concentrations of $X$. somloënsis and $5 \mu \mathrm{g} / \mathrm{plate}$ concentration of $C$. islandica methanol extracts have not any antimutagenic activity on the same strain. The results of bacterial antimutagenicity assays were presented in Table 2.

The results of antimutagenicity assays performed with $Z$. mays seeds show that all methanol extracts have antimutagenic effects against $\mathrm{NaN}_{3}$ mutagenicity on seed germination. The mitotic index values of germinated seeds were increased parallel with increasing concentrations of the test materials (Table 3).

Discussion. Mutations have wide range effects on living organisms and are occasionally associated with forming various diseases including Tay-Sachs disease, Huntington's disease, Thalassemia, Cancer, 
The mutagenicity assay results of the methanol extracts for $S$. tyhimurium TA1535 and TA1537 bacterial tester strains

\begin{tabular}{|c|c|c|c|c|c|}
\hline \multirow{3}{*}{ Test Items } & \multirow{3}{*}{$\begin{array}{c}\text { Concentration, } \\
\mu \mathrm{g} / \text { plate }\end{array}$} & \multicolumn{4}{|c|}{ Number of revertants } \\
\hline & & \multicolumn{2}{|c|}{ TA1535 } & \multicolumn{2}{|c|}{ TA1537 } \\
\hline & & Mean \pm S.E. & Mutat., \% & Mean \pm S.E. & Mutat., \% \\
\hline NaN3* & 1 & $451.25 \pm 05.53$ & & & \\
\hline 9-AA* & 40 & & & $620.25 \pm 02.29$ & \\
\hline DMSO$^{*}, \mu \mathrm{l} /$ plate & $\begin{array}{r}100 \\
0.05\end{array}$ & $\begin{array}{l}23.25 \pm 01.44 \\
20.25 \pm 02.02\end{array}$ & - & $\begin{array}{l}31.25 \pm 01.55 \\
25.75 \pm 02.10\end{array}$ & - \\
\hline C. islandica & $\begin{array}{r}0.5 \\
5 \\
0.05\end{array}$ & $\begin{array}{l}19.75 \pm 00.48 \\
19.75 \pm 01.25 \\
19.25 \pm 01.03\end{array}$ & $\begin{array}{l}- \\
- \\
-\end{array}$ & $\begin{array}{l}28.25 \pm 01.25 \\
26.50 \pm 01.26 \\
25.75 \pm 01.80\end{array}$ & $\begin{array}{l}- \\
- \\
-\end{array}$ \\
\hline$P$. furfuracea & $\begin{array}{r}0.5 \\
5 \\
0.05\end{array}$ & $\begin{array}{l}20.75 \pm 01.25 \\
21.25 \pm 00.48 \\
19.25 \pm 00.48\end{array}$ & $\begin{array}{l}- \\
- \\
-\end{array}$ & $\begin{array}{l}27.50 \pm 01.26 \\
27.75 \pm 02.78 \\
24.50 \pm 01.66\end{array}$ & $\begin{array}{l}- \\
- \\
-\end{array}$ \\
\hline X. somloënsis & $\begin{array}{r}0.5 \\
5\end{array}$ & $\begin{array}{l}19.50 \pm 00.87 \\
15.75 \pm 01.49\end{array}$ & $\begin{array}{l}- \\
-\end{array}$ & $\begin{array}{l}26.75 \pm 01.44 \\
27.50 \pm 01.71\end{array}$ & $\begin{array}{l}- \\
-\end{array}$ \\
\hline
\end{tabular}

* $\mathrm{NaN}_{3}$ and 9-AA were used as positive controls for $S$. typhimurium TA1535 and TA1537 strains, respectively. DMSO (Dimethyl sulfoxide) was used as negative control.

The antimutagenicity assay results of the methanol extracts for $S$. typhimurium TA1535 and TA1537 bacterial tester strains

\begin{tabular}{|c|c|c|c|c|c|}
\hline \multirow{3}{*}{ Test Items } & \multirow{3}{*}{$\begin{array}{c}\text { Concentration, } \\
\mu \mathrm{g} / \text { plate }\end{array}$} & \multicolumn{4}{|c|}{ Number of revertants } \\
\hline & & \multicolumn{2}{|c|}{ TA1535 } & \multicolumn{2}{|c|}{ TA1537 } \\
\hline & & Mean \pm S.E. & Inhib., \% & Mean \pm S.E. & Inhib., \% \\
\hline NaN3* & 1 & \multicolumn{2}{|l|}{$451.25 \pm 05.53$} & \multirow{2}{*}{\multicolumn{2}{|c|}{$62025+0229$}} \\
\hline $9-\mathrm{AA}^{*}$ & 40 & & & & \\
\hline \multirow{2}{*}{$\mathrm{DMSO}^{*}, \mu \mathrm{l} /$ plate } & 100 & & & & \\
\hline & 0.05 & $23.25 \pm 01.44$ & & $31.25 \pm 01.55$ & \\
\hline \multirow[t]{3}{*}{ C. islandica } & 0.5 & $465.00 \pm 04.97$ & - & $210.00 \pm 03.89$ & $66.14 * *$ \\
\hline & 5 & $468.25 \pm 03.45$ & - & $298.00 \pm 02.97$ & $51.95 * *$ \\
\hline & 0.05 & $459.25 \pm 09.51$ & - & $627.50 \pm 03.28$ & - \\
\hline \multirow[t]{3}{*}{$P$. furfuracea } & 0.5 & $485.75 \pm 03.64$ & - & $462.00 \pm 05.92$ & $25.51 * *$ \\
\hline & 5 & $477.50 \pm 04.35$ & - & $266.00 \pm 02.86$ & $57.11 * *$ \\
\hline & 0.05 & $454.50 \pm 03.75$ & - & $428.25 \pm 04.35$ & $30.95 * *$ \\
\hline \multirow[t]{3}{*}{$X$. somloënsis } & 0.5 & $459.75 \pm 04.11$ & - & $631.25 \pm 04.87$ & - \\
\hline & 5 & $461.75 \pm 05.37$ & - & $624.00 \pm 03.03$ & - \\
\hline & & $462.00 \pm 02.97$ & - & $629.00 \pm 02.94$ & - \\
\hline
\end{tabular}

* $\mathrm{NaN}_{3}$ and 9-AA were used as positive controls for $S$. typhimurium TA1535 and TA1537 strains, respectively. DMSO (Dimethyl sulfoxide) was used as negative control. ** $\mathrm{p}<0,05$. 
et cetera, as grave human diseases [1, 2, 35]. Because of relationship between mutations and diseases, researching of mutations has become great importance to prevent harmful effects of mutations. Previous studies showed that lichens have several biological effects on living organisms such as antimicrobial, antiviral, antioxidant and antimutagenic effects [5, 8, $12,36-38]$. Depending on mentioned information, our study was designed to determine mutagenic and antimutagenic properties of methanol extracts from C. islandica, $P$. furfuracea and $X$. somloënsis.

According to this study, all methanol extracts have not mutagenic activity on testing organisms, and they can be considered as genotoxically safe at tested concentrations.

In antimutagenicity assays performed with $S$. typhimurium strains and $Z$. mays seeds, known mutagens $\mathrm{NaN}_{3}$ and 9-AA were used to determine antimutagenic properties of lichen extracts. $\mathrm{NaN}_{3}$ causes point mutations in several organisms including bacteria, plants and animals [39-41]. A lot of studies showed that mutagenesis mechanism of $\mathrm{NaN}_{3}$ is associated with its metabolite called L-azidoline [40-42]. It can be seen that the lichen extracts inhibit mutagenic activity of $\mathrm{NaN}_{3}$ on $Z$. mays seed

Table 3

The antimutagenicity assay results of the methanol extracts for Mitotic index (MI) values of root tips in $Z$. mays.

\begin{tabular}{l|c|c}
\hline Test Items & $\begin{array}{c}\text { Concentra- } \\
\text { tion, } \\
\mu \mathrm{g} / \text { plate }\end{array}$ & Mitotic index \pm S.E. \\
\hline NaN3* & 800 & No Germination \\
Negative control* & - & $19.73 \pm 1.52$ \\
C. islandica & 5 & $10.03 \pm 1.70 * *$ \\
& 10 & $14.68 \pm 0.40^{* *}$ \\
& 20 & $15.95 \pm 0.70^{* *}$ \\
P. furfuracea & 40 & $17.13 \pm 0.43 * *$ \\
& 5 & $10.53 \pm 1.06 * *$ \\
& 10 & $15.57 \pm 0.11 * *$ \\
X. somloënsis & 20 & $16.78 \pm 1.29 * *$ \\
& 40 & $17.59 \pm 0.20 * *$ \\
& 5 & $09.40 \pm 1.71 * *$ \\
& 10 & $13.70 \pm 1.94 * *$ \\
& 20 & $15.30 \pm 1.02 * *$ \\
& 40 & $18.43 \pm 0.79 * *$ \\
\hline
\end{tabular}

* $\mathrm{NaN}_{3}$ was used as positive control and distilled water as negative control. ${ }^{* *} \mathrm{p}<0.05$. germination. The antimutagenicity of lichen extracts may be explained with their inhibitor activity on the production of L-azidoalanine. Although, they do not inhibit $\mathrm{NaN}_{3}$ mutagenesis on $S$. typhimurium TA1535 strain. S. typhimurium TA1535 strain has a defect in $u v r B$ gene region, which encodes a subunit of UvrABC endonuclease multienzyme complex, and it is deficient in DNA repair [23, 43]. The difference between results obtained from antimutagenicity assays performed with $S$. typhimurium TA1535 and $Z$. mays seeds may be explained that antimutagenic effects of lichen extracts on $\mathrm{NaN}_{3}$ mutagenesis may be related with their stimulant effects on DNA repair enzyme systems.

The other mutagen was 9-aminoacridine, which is a member of acridine group and is known as a model frame-shift mutagen [40, 44]. In the frameshift mutagenesis mechanism, acridines bind to DNA noncovalently by intercalation. Their planar aromatic ring systems insert into the helix parallel to the base pairs $[40,45,46]$. 9-AA used in this study is a simple intercalator. Through intercalation, 9-AA induces frame-shift mutations at hotspots in which a single base, especially guanine, is repeated [40, 46-48]. The antimutagenicity assay performed with S. typhimurium TA1537 and 9-aminoacridine depends on the inhibition of this mechanism by test substances, which were thought as antimutagenic. In this paper, $C$. islandica and $P$. furfuracea methanol extracts have antimutagenic activity in TA1537 strain at different concentrations. These effects may be due to their inhibition capabilities by blocking 9-AA binding to DNA.

In conclusion, all methanol extracts examined in this paper could be considered as genotoxically safe at the tested concentrations and some of them provided important antimutagenic properties. Further investigation is necessary because these activities are valuable towards an extension of the employ of these drugs as new phytotherapeutic or preservative ingredients.

$$
\begin{gathered}
\text { A. Aslan, M. Gulluce, G. Agar, } \\
\text { M. Karadayi, S. Bozari, F. Orhan } \\
\text { МУТАГЕННЫЕ И АНТИМУТАГЕННЫЕ } \\
\text { СВОЙСТВА НЕКОТОРЫХ ВИДОВ } \\
\text { ЛИШАЙНИКОВ, ПРОИЗРОСТАЮЩИХ } \\
\text { В ВОСТОЧНОЙ АНАТОЛИИ (ТУРЦИЯ) }
\end{gathered}
$$

Целью работы было изучить мутагенный и антимутагенный потенциал метанольных экстрактов Cetraria islandica (L.) Ach. (Parmeliaceae), Pseudever- 
nia furfuracea (L.) Zopf (Parmeliaceae) и Xanthoparmelia somloënsis (Gyeln.) Hale (Parmeliaceae) - лишайников из восточной части Турции. Ни один из экстрактов не показал мутагенной активности в тестах Эймса и Z. mays MI. Более того, некоторые экстракты проявляли заметную антимутагенную активность против 9-амино-акридина в тесте Эймса. Уровень ингибирования варьировал от $25,51 \%$ ( $P$. furfuracea) до 66,14 \% ( $C$. islandica). Кроме того, все экстракты проявляли значительную антимутагенную активность против азида натрия в Z. mays MI тесте. Все экстракты могут считаться генотоксично безопасными в исследованных концентрациях.

\section{REFERENCES}

1. Shinohara $K$. Biophylactic and anticarcinogenic functions of vegetables and Fruits, Nippon Nogeikagaku Kaishi // J The Japan Soc Biosci Biotech and Agrochem, 1993, vol. 67, p. 42-45.

2. Nakasugi T. et al. Antimutagens in gaiyou ( $A r-$ temisia argyi Levl. et Vant.) // J Agricul Food Chem, 2000, vol. 48, p. 3256-3266.

3. Ozbek $T$. et al. Investigation of the antimutagenic effects of methanol extract of Astragalus L. species growing in Eastern Anatolia Region of Turkey // Fresen Environ Bull, 2008, vol. 17, p. 2052-2058.

4. Ozbek T. et al. Antimutagenic activities of methanol extracts of some endemic Astragalus species evaluated by Ames Salmonella/Microsomal Test // Asian J Chem, 2009, vol. 21, p. 451-458.

5. Zeytinoglu $H$. et al. Determination of Genotoxic, Antigenotoxic and Cytotoxic Potential of the Extract from Lichen Cetraria aculeata (Schreb.) Fr. in vitro // Phytother Res, 2008, vol. 22, p. 118-123.

6. Kundu J.K. et al. Breaking the relay in deregulated cellular signal transduction as a rationale for chemoprevention with anti-inflammatory phytochemicals // Mutat Res, 2005, vol. 591, p. 123-146.

7. Tsukagoshi S. et al. Protein-bound polysaccharide preparation, PS-K, effective against mouse sarcoma 180 and rat ascites hepatoma $\mathrm{AH}-13$ by oral use // Japan J Cancer Res (Gann), 1974, vol. 65, p. 557-558.

8. Agar G. et al. Mutation preventive and antigenotoxic potential of methanol extracts of two lichen // J Med Plants Res, 2010, vol. 4, p. 2132-2137.

9. Cansaran D. et al. Determination of Usnic Acid in some Rhizoplaca species from the Middle Anatolia and their antimicrobial activities // Zeitschrift für Naturforschung, 2006, vol. 61, p. 47-51.

10. Odabasoglu F. et al. Comparison of Antioxidant Activity and Phenolic Content of Three Lichen Species // Phytother Res, 2004, vol. 18, p. 938-941.

11. Ozturk $S$. Yüzyılların Çevrecisi Likenler (published in
Turkish) // Bilim ve Teknik, 1995, vol. 328, p. 7479.

12. Aslan A. et al. Antioxidant and antimicrobial properties of the lichens Cladonia foliacea, Dermatocarpon miniatum, Everinia divaricata, Evernia prunastri, and Neofuscella pulla // Pharm Biol, 2006, vol. 44, p. 247-252.

13. Gulluce $M$. et al. Screening the antioxidant and antimicrobial properties of the lichens Parmelia saxatilis, Platismatia glauca, Ramalina pollinaria, Ramalina polymorpha and Umbilicaria nylanderiana Phytomedicine, 2006, vol. 13, p. 515-521.

14. Dobson F.S. Lichens, an Illustrated Guide to the British and Irish Species, Slough, UK: Richmond Publ.Co. Ltd., 2000.

15. Poelt J. et al. Bestimmungsschlüssel Europäisher Flechten, Ergänzungsheft II //Bibliotheca Lichenologica, 1981, vol. 16, p. 1-390.

16. Purwis O.W. et al. The Lichen Flora of Great Britain and Ireland, London, England: Natural History Museum Publications in association with The British Lichen Society, 1992.

17. Lin J. et al. Preliminary screening of some traditional zulu medicinal plants for anti-inflammatory and anti-microbial activities // J Ethnopharmacol, 1999, vol. 68, p. 267-274.

18. Oh H.T. et al. Antioxidative and antimutagenic activities of $70 \%$ ethanol extract from masou salmon (Oncorhynchus masou) // Toxicol In Vitro, 2008, vol. 22, p. 1484-1488.

19. Santana-Rios G. et al. Potent antimutagenic activity of white tea in the Salmonella assay // Mutat Res, 2001, vol. 495, p. 61-74.

20. Yu Z et al. A comparison of whole wheat, refined wheat and wheat bran as inhibitors of heterocyclic amines in the Salmonella mutagenicity assay and in the rat colonic abberant crypt focus assay // Food Chem Toxicol, 2001, vol. 39, p. 655-665.

21. Konuk M. et al. Determination of genotoxic effect of boron on Allium cepa root meristematic cells // Pak J Bot, 2007, vol. 39, p. 73-79.

22. Yüzbaşıoğlu D. et al. Cytological effects of herbicide racer flurochloridone on Allium cepa // Caryologia, 2003, vol. 56, p. 97-105.

23. Mortelmans K. et al. The Ames Salmonella/microsome mutagenicity assay // Mutat Res, 2000, vol. 455 , p. $29-60$.

24. Maron D.M. et al. Revised methods for the Salmonella mutagenicity test // Mutat Res, 1983, vol. 113, p. 173-215.

25. Evandri M.G. The antimutagenic activity of Lavandula angustifolia (lavender) essential oil in the bacterial reverse mutation assay // Food Chem Toxicol, 2005, vol. 43, p. 1381-1387.

26. Santos F.V. et al. Mutagenicity of Mouriri pusa 


\section{A. Aslan, M. Gulluce, G. Agar et al.}

Gardner and Mouriri elliptica Martius // Food Chem Toxicol, 2008, vol. 46, p. 2721-2727.

27. Varella S.D. et al. Mutagenic activity in waste from an aluminum products factory in Salmonella/microsome assay // Toxicol In Vitro, 2004, vol. 18, p. 895-900.

28. Vargas V.M.F. et al. Mutagenic activity detected by the Ames test in river water the influence of petrochemical industries // Mutat Res, 1993, vol. 319, p. $31-45$.

29. Ikken $Y$. et al. Antimutagenic effect of fruit and vegetable ethanolic extracts against $N$-nitrosamines evulated by the Ames test // J Agr Food Chem, 1999, vol 47, p. 3257-3264.

30. Negi P.S. et al. Antioxidant and antimutagenic activities of pomegranate peel extracts // Food Chem, 2003, vol. 80, p. 393-397.

31. Jiang $W$. et al. Effects of $\mathrm{Pb} 2+$ on root growth, cell division, and nucleolus of Zea mays (L.) // B Environ Contam Tox, 2000, vol. 65, p. 786-793.

32. Sharma A.K. et al. Chromosome Techniques-Theory and Practice, Second Edition, Baltimore, MD: University Park Press, 1982.

33. Agar G. et al. The protective role of selenium against the genotoxicity induced by aflatoxin B1 in root cells of crop plants // Fresen Environ Bull, 2005, vol. 14, p. 849-853.

34. Kiran $Y$. et al. The effects of the lead on the seed germination, root growth, and root tip cell mitotic divisions of Lens culinaris (Medik.) // GUJ Sci, 2005, vol. 18, p. 17-25.

35. Vallance $H$. et al. Carrier Testing for AutosomalRecessive Disorders // Crit Rev Cl Lab Sci, 2003, vol. 40, p. 473-497.

36. Abonyi D.O. et al. Plants as sources of antiviral agents // Afr J Biotechnol, 2009, vol. 8, p. 39893997.

37. Cansaran D. et al. HPLC analysis of the Usnic Acid in some Ramelina species from Anatolia and Investigation of their antimicrobial activities // Pharm Biol, 2007, vol. 45, p. 77-81.

38. Fazio A.T. et al. Lichen secondary metabolites from the cultured lichen mycobionts of Teloschistes chrysophthalmus and Ramalina celastri and their antiviral activities // Z Naturforsch C, 2007, vol. 62, p. 543-549.

39. Grant W.F. et al. Comparative mutagenecity of chemicals selected for test in the International Program on Chemical Safety's collaborative study on plant systems for the detection of environmental mutagens // Mutat Res, 1994, vol. 310, p. 187209.

40. Gulluce M. et al. Mutagenic and antimutagenic effects of some Astragalus species grown in the Eastern Anatolia region of Turkey // Phytother Res, 2010, vol. 24, p. 1014-1018.

41. Sadiq M.F. et al. Mutagenicity of sodium azide and its metabolite azidoalanine in Drosophila melanogaster // Mutat Res, 2000, vol. 469, p. 253-257.

42. Owais W.M. et al. Metabolic activation of the mutagen azide in biological systems // Mutat Res, 1988, vol. 197, p. 313-323.

43. Arikan E. et al. Sequences of the E. coli uvrB gene and protein // Nucleic Acids Res, 1986, vol. 14, p. 2637-2650.

44. Ferguson L.R. et al. The genetic toxicology of acridines // Mutat Res, 1991, vol. 258, p. 123-160.

45. Lerman L.S. Structural considerations in the intercalations of DNA and acridines // J Mol Biol, 1961, vol. 3, p. 18-30.

46. Neidle S. et al. Structural and sequence-dependent aspects of drug intercalation into nucleic acids // CRC Crit Rev Biochem, 1984, vol. 17, p. 73-121.

47. Ferguson L.R. et al. Frameshift mutagenesis by acridines and other reversibly-binding DNA ligands // Mutagenesis, 1990, vol. 5, p. 529-540.

48. Hoffmann G.R. et al. Frameshift mutations induced by three classes of acridines lac $Z$ reversion assay in Escherichia coli: potency of responses and relationship to slipped mispairing models // Environ Mol Mutagen, 2003, vol. 42, p. 111-121.

Received 18.08.11 